\title{
The argumentative litotes in The Analects
}

\author{
Ying Yuan \\ Department of English, School of Foreign Languages, Soochow University, Suzhou, Jiangsu 215006, \\ China \\ E-mail: szyuanying@sina.com
}

\begin{abstract}
Litotes, often confused with meiosis and understatement, has long suffered neglect. By comparing synonymous key words in previous definitions, this essay defines litotes as "a trope in which an affirmative is expressed by the negation of its opposite," and for the first time classifies litotes into three subtypes based upon Aristotle's study of opposition: contradictory, contrary and relative. Focusing particularly on the strong contradictory type of litotes and its realization in The Analects of Confucius, with its nearly one hundred double negation litotes, we find they prominently serve the logical functions of achieving high probability, providing a sophisticated major premise, and elaborating strict definitions. Further, the essay argues that this strong argumentative function in logic leads to litotes' epistemic power, a promising dimension for future research.
\end{abstract}

Keywords: Rhetorical figures, tropes, logic, epistemic rhetoric, negation

\section{Introduction}

Scholarship on figures of speech in the past decades has contributed greatly to exploring the functions beyond the aesthetic $([13,27,29])$; however, most research only investigates a few popular tropes (metaphor and metonymy in particular), leaving many important figures still unattended. Litotes, a powerful argumentative figure, is unduly and unfortunately neglected, in rhetorical scholarship as well as in argumentation studies, and, despite its correlation with morpholexical signatures of negation, it is virtually unknown in computational argument studies. This essay begins a systematic investigation of the argumentative functions of litotes, first by briefly tracing its scholarly history and then by closely examining the Chinese classic of Confucius' Analects, a particularly rich text for the exploration of litotes, in part because of its argumentative style and in part because of the special resources of the Chinese language. This inquiry combines qualitative research methods with a quantitative approach, progressing logically with description illustrated by preliminary statistics and sample analyses. The theoretical support comes mainly from Aristotle's Categories [2], Rhetoric [1], and Interpretation [2], and from Perelman \& Olbrecht-Tyteca's The New Rhetoric: A Treatise on Argumentation [37] with valuable reliance on Wang's Ancient Chinese Language [42] and Gao's On Chinese Grammar [17].

This research is through manual inspection. The complications of litotes types make automatic detection challenging at this stage; certainly, computational detection could not catch them all currently (unless tuned so broadly as also to generate many false positives), so I proceeded by manual inspection of The Analects: multiple careful readings, line-by-line, to ensure completeness and precision. The results not only justify this process, but they identify the features which can help automate such processes in the future. The inquiry, while confirming litotes familiar roles, discovers several new argumentative functions. 


\section{A universal figure with negligible research}

Litotes - most generally known as an affirmative expressed by the negation of its opposite (as in "litotes is not an insignificant figure") - is ubiquitous. Negation, of course, is universal. Horn in his renowned A Natural History of Negation claims, "All human systems of communication contain a representation of negation." ([21]:xiii), and later in The Expression of Negation he adds it "is a sine qua non of every human language, but is absent from otherwise complex systems of animal communication" ([23]:1). Burke, indeed, defines man as "Inventor of the negative" ([6]:498), and Royce calls "[t]he notrelation... one of the simplest and most fundamental relations known to the human mind" ([39]:265). But it is important to note that the function of this relation is not always direct negation, and litotes is the most pervasive way that negation is deployed to a different purpose; in fact, to its inverse purpose, affirmation.

Litotes is universal in ordinary language and in texts of all domains and genres - literary and historical; philosophical and scientific; trivial and profound. Litotes by negation frequently appear in Homer's Iliad and Odyssey, Thucydides' History of the Peloponnesian War, Cicero's Brutus and De Oratore, Kafkas' Das Schloss, More's Utopia and King Richard III, Confucius' Analects, etc. (cf. [12,19,30,31, 38]) However, in sharp contrast to its prevalence in language, its prevalence in research is meager - only a few dozen articles and two monographs. ${ }^{1}$

The most systematic of this existing research is perhaps Hoffmann's dissertation-based monograph, Negatio Contrarii: A Study of Latin Litotes [19]. She defines litotes as an evaluative expression expressed through the negation of its opposite ([19]:42) - we will return to this definition - and plots out the syntactic features, semantic properties and pragmatic functions associated with this account. The functions she finds are mainly argumentative: periphrastic, evaluative, focusing. The first two can be regarded as ethotic, and the last as effecting salience. This is a good start, but there are other argumentative functions; for example, logical functions. This study aims to prove that litotes can help establish the enthymeme, "the substance of rhetorical persuasion" ([1]:20), with higher probability and more resistance to refutation, and that it can serve as a sophisticated major premise. Further, while Hoffmann and other researchers (such as [14,24,25,43]) have offered their respective definitions and touched upon litotic types, they have not provided adequate justifications, leading to considerable confusion. We seek, in this paper, theoretical support for understanding the key concepts of litotes, chiefly negation and opposition (shown in the next section), so to establish a solid definition and classification for the figure as a foundation for the argumentative functions and corresponding forms.

\section{Definition and classification}

Litotes, a Greek word, like many rhetorical terms, means 'plainness,' 'simplicity,' or 'smallness,' with alternate spellings such as liptote, lyptote and leptotes ([9]:258-9). It first shows up in the rhetorical tradition with the first century BCE rhetorician Dionysius of Halicarnassus, who uses it in a general way to characterize the muted, understated style of Isocrates [38], and begins to associate with a specific device in the fourth century CE. The Grammarian Servius, for instance, calls it a "kind of figure"

\footnotetext{
${ }^{1}$ Most closely related articles have been included in Sections 2 and 3; the two monographs are Hoffmann's Negatio Contrarii [19], illustrated in the next paragraph, and Mathias Mayer's Franz Kafkas Litotes: Logik und Rhetorik der doppelten Verneinung [30]. Other significant work on litotes in this narrow group includes articles by van der Wouden [41], Horn [22], Neuhaus [35], and the very recent work by Horn [20].
} 
which "indicates the contrary" ([38]:353n4). But - like many other rhetorical terms, most notoriously the figures - litotes accrues various overlapping and sometimes conflicting definitions over the millennia. The common features can, however, be extracted as a first pass at a stable and fruitful definition. In the established dictionaries we find accounts such as these:

Definition 1. A figure of speech, in which an affirmative is expressed by the negative of the contrary. (The Oxford English Dictionary [36])

Definition 2. Understatement in which an affirmative is expressed by the negative of the contrary (Merriam-Webster's International Dictionary of the English Language [33])

Definition 3. A figure of speech in which an affirmative is expressed by the negation of its opposite. (The American Heritage Dictionary of the English Language [34])

In more scholarly treatments we get somewhat richer and more useful accounts for argument analysis, most of them adumbrating both form and function:

Definition 4. The figure of speech by which a (nearly always) evaluative expression is periphrased by the negation of its opposite. (Hoffmann [19]: 42)

Definition 5. Litotes occurs when a speaker avoids making an affirmative claim directly and instead denies its opposite. Often this amounts to a double negative. (Farnsworth [14]:204)

Definition 6. A stylistic device which seeks to highlight an idea, an impression or a judgement. The negation of the contrary idea takes the place of the simple affirmative expression, in order to give it greater weight, hence [Servius's use of the] superlative, strenuissima. (Pontier, paraphrasing Porphyrio and Servius [38]:353-4)

The similarities among these accounts mainly lie in the kernel of each definition, referencing the paired formal characteristics of negative/negation with the semantic properties of contrary/opposite.

But similar as they are, identical they are not. Even for the seeming synonyms of negative and negation in this context, the latter seems to fit more. In comparing these two and other related synonymous terms, Hass concludes that negation is "originary" and "generative," as "[t]he Latinate suffix "-ion' denotes a verbal action made into a noun, or made, we might say, objective, perhaps even concrete... Negation then becomes the actual or actualized activity of negating" ([18]:11), an insight that led him to entitle his book, Hegel and the Art of Negation. With regards to contrary and opposite, in the interests of precision, they are even harder to treat as equal. The former is categorized as one type of the latter by Aristotle (as elaborated below), an understanding adopted by later logicians. With these considerations, favouring opposite and negation, a blend of the definitions from The American Heritage Dictionary and Hoffmann (using both terms), provides us with the best working foundation.

As to the type of figure litotes belongs to, these definitions reveal it to be clearly an intermediate kind, with traits of both the tropes and the schemes, much like simile. Simile is universally categorized as a trope because of its conceptual character. Like a metaphor, the prototypical trope, it maps features across conceptual domains. But the one that distinguishes it from metaphor is the presence of a comparison marker, in English like or as; that is, similes require morpholexical-syntactic indexes, which give them some of the formal character of schemes. Litotes is the same. All the litotic types (double negation, most notably) require morpholexical-syntactic indexes. Litotes has the conceptual character of tropes (hinging on opposition) and the formal character of schemes (requiring the presence of negation markers). 
It has not escaped our notice that morpholexical-syntactic signatures of litotes make the figure a more tractable trope than most for computational purposes. Computers do much better with formal patterns than with conceptual patterns. Finding a litotes is an easier proposition for a machine than finding a metaphor or a metonymy. And, to the extent that its form correlates with a range of argumentative functions, finding them offers important potentialities for such jobs as argument mining.

But categorially, we do have a decision to make, one that is licensed by tradition. Litotes is overwhelmingly, like simile, regarded as a trope in the rhetorical literature, a treatment we find very congenial. Firstly (and again like simile), its effect leverages semantics far more than syntax or lexis. Unlike, say rhyme or isocolon or antimetabole, the form contributes little to its salience as a device. Secondly, even its morpholexical-syntactic signature is semantically restricted (to markers of negation and opposition). Thirdly, it seems reasonable, when both formal and semantic characteristics are present, to give the nod to semantics; in categorical terms, tropes trump schemes. These considerations bring us to our definition of litotes: a trope in which an affirmative is expressed by the negation of its opposite.

\section{Subtyping litotes}

The subclassification of litotes, with its attendant definitions, offers further challenges. A few subclassifications have been adumbrated in the literature (e.g. [19,24,43]), but none of them come with satisfactory criteria, which leaves litotes looking like a hodgepodge of subtypes. We propose a classifying criterion keyed to the central concept in our working definition: Aristotle's interpretation of opposition in Categories can well serve as a criterion for classifying litotes. The Philosopher says

Things are said to be opposed to one another in four ways: as relatives or as contraries or as privation and possession or as affirmation and negation. Examples of things thus opposed (to give a rough idea) are: as relatives, the double and the half; as contraries, the good and the bad; as privation and possession, blindness and sight; as affirmation and negation, he is sitting - he is not sitting. [2]:19

From these four opposing ways, we derive three subcategories of litotes, which rather naturally characterize the many instances cited to exemplify the figure: contradictory, contrary, and relative. Our threefrom-four derivation is because we feel Aristotle's third opposition, privation and possession, absorbs easily into his second opposition, the contraries, for sight and blindness are special cases of contraries, like attractiveness and ugliness, intelligence and stupidity. ${ }^{2}$ We also choose to label Aristotle's affirmation and negation more elegantly as contradiction, since he says himself in De Interpretatione, "Let us call an affirmation and a negation which are opposite a contradiction" ([2]:27). Based upon these dimensions of opposition, we are then justified to have three types of litotes/"negation of its opposite": contradictory litotes (negation + negation), contrary litotes (negation + antonym), relative litotes (negation + correlation/meronymy).

\section{A. Contradictory litotes (negation + negation)}

a) Thus I consent, sir, to this Constitution, because I expect no better, and because I am not sure that it is not the best. ([15])

\footnotetext{
${ }^{2}$ This integration might be controversial (or needs further illustration), as noted by one reviewer who observes that privation has not been discussed in connection with litotes. But nothing much hinges on our absorption of privation (rather than the strategy of ignoring privation that others adopt). In any case, the neglect of privation by other thinkers on litotes certainly supports our three subcategories of litotes.
} 
b) It was not without satisfaction that I recognized my own handiwork in a great cut under his right eye and a considerable discolouration round the socket. ([40]:341)

c) His wife was not always out of humor, nor his home always uncomfortable; and in his breed of horses and dogs, and in sporting of every kind, he found no inconsiderable degree of domestic felicity. ([3]:297)

In the sense of contradictory as 'mutually opposed,' the above classic examples of contradictory litotes show that in this type the first negation (a) is in the form of a negator, such as not, no, or nor; the second negation (b), which denotes the contradictory opposite, is often formed by a negator as well, usually not, but also by a negative/privative preposition like without; the third type (c), similarly with a negator and a negative/privative preposition, and also with negator paired with a negating affix, such as in-, un-, dis-, or -less. ${ }^{3}$

\section{B. Contrary litotes (negation + antonym of a lexeme)}

a) My guardian will be awfully keen for you to come and stay with us. He is not half bad when you know him. ([16]:66) ${ }^{4}$

b) Chomsky is no idiot. (common phrasing)

c) It does not hurt the newest comer to sweep out the office if necessary. ([7]:3)

In the sense of contrary as 'conflicting or antagonistic,' contrary litotes can implicate negatively valenced words from various parts of speech, but, as Hoffmann ([19]:58) points out, adjectives are the most active in forming this type of English litotes.

\section{Relative litotes (negation + correlation/meronymy)}

a) The class is in chaos, but it is not the students' fault.

b) I just made moderate suggestions, as my position was not to lead.

c) Not all teachers of English are experienced.

d) This plant is not to be found everywhere.

In the sense of 'mutually defining antonyms,' first two of these hypothetical examples (a and b) are of the correlative or reciprocal subtype. Here, student is opposite to teacher, lead to follow; in addition, Fahnestock ([13]:49) mentions other such pairs, including cause and effect, parent and child, doctor and patient - lexical opposites based on reciprocal determination (the concept of parent is impossible without the concept of child, for instance). And we think, besides verb and noun correlative pairs, adjectives or adverbs can also pair up, e.g. academic(ally)/administrative(ly), but nouns should be more active in this relationship. The last two litotes in this category (c and d) exemplify meronymy or whole-part relation: all is opposite to some; it also includes everywhere/somewhere, everyone/someone, entirely/partially, always/sometimes, and so forth.

Comparatively speaking, the relative type is most neglected in litotes studies, due to lacking adequate dimensions in understanding "opposite," but it offers a promising scope for future inquiry; the contrary

\footnotetext{
${ }^{3}$ In Horn's "Duplex, negation, affirmat, ... the economy of double negation," the happy/unhappy pair is treated as "contrary opposition," white/non-white as "contradictory opposition" [22]. This is confusing, for the semantics of all negating affixes mean not, which is definitely regarded as contradictory by Aristotle. So we treat them equally as contradictory.

${ }^{4}$ As Hoffmann [19] summarized that adjectives should be most active in forming this type of English litotes, here are more examples: "John is a man of no common ability."; "This is no rare occurrence."; "It gave me no small pleasure to receive a letter from you."
} 
type seems to be the most generative, as it can produce countless litotes with the sea of antonyms, but sometimes we may hesitate about their real identity - whether the negation plus antonym is uttered intentionally to replace the affirmative form; the contradictory type, with its schematic double negation, proves most uncontroversial and distinguishes itself markedly from other related figures, such as meiosis, irony, and oxymoron. So it serves as a natural prototype of litotes and we take up its usages in a most influential Chinese classic, The Analects of Confucius ([10,11]).

\section{Litotes in The Analects}

The Analects is a collection of 20 passages recording mainly the dialogues between Confucius and his disciples on all major aspects of life. Since its assembly after the Master's death (479 BCE), the text has exerted tremendous influence both inside and outside of China. Of the various Chinese and English versions, we have chosen the authoritative Liu Baonan edition (Qing Dynasty [11]) and D.C. Lau's highly recognized English translation [10] to extract the typical litotes data for analysis.

Taking into account the three above-mentioned subtypes, it is no exaggeration to say that this classic is brimming with litotes. By concentrating on contradictory litotes - most identifiable for its highly schematic double negation (DN), and therefore also the most computationally amenable - we have detected throughout the entire collection (11750 Chinese characters), $97 \mathrm{DN}$ pairs. ${ }^{5}$ They can be further divided into two: conditional double negations (CDNs) and non-conditional double negations (NonCDNs); the conditional (66 pairs) mainly achieve logical function while the non-conditional (31 pairs) emphasize the affirmative.

The high frequency of DN litotes (near 100 pairs) may result from various factors, among which we attribute it first to the unusual richness of Chinese negators. According to Grammarian Wang ([42]:260), there exist in ancient Chinese nine frequently used negators: “不” (bù), “弗” (fú), “四” (mú), “勿” (wù), “未” (wèi), “否” (fǒu), “非” (fēi), “无” (wú), “莫” (mò). In The Analects, all except “弗” (fú) and “否” (fóu) have appeared and we actually find one more adverb negator: “末” (mò) collocated with “不” (bù) for three times. Among all the negator collocations (about 20) in this analyzed text, the highest frequency goes to “不” (bù)... “不” (bù) (48 pairs), next “无” (wú)... “不” (bù) and “不” (bù)... “无” (wú) (11 for each). As stated by Lv [28] and Gao [17], “不” (bù) (like not) is a dominating Chinese negator. Almost all the Chinese DN litotes are formed via two negators. As to the translated versions, the first negation is often formed by the negator of not, no, or never, in the order of frequency, the second negation either by a negator or a semantically richer negative word, such as unless or without. Comparatively speaking, DNs seem easier to formulate in Chinese (esp. ancient Chinese) because of its richer inventory of negators, and DN appears to achieve a stronger force with the prominently aligned negators than with one negator plus a negative lexeme (conjunction or preposition, etc.) or a negative-affix word.

As we will argue, however, litotes confers a distinctive style of argumentation. It condenses a subtle and resilient epistemic argument structure that both characterizes the ethos of The Analects and reflects the culture that has taken up and propagated its litotic formulations. On whether the preponderance of negators in ancient Chinese molded the argumentation of Confucius or whether Confucius harnessed that preponderance to his style, we have no position. It is a chicken or egg question. But The Analects presents us with a laboratory of litotes in which we can explore the argumentation of affirming by denying.

\footnotetext{
${ }^{5}$ We exclude, of course, non-affirmative double negations, especially parallel negations. For example: 子贡 日：“贫而无谄, 富而无骄, 何如?” (Tzu-Kung [Master's disciple] said, “Poor without being obsequious, wealthy without being arrogant. What do you think of this saying?") - Passage I, Section 15.
} 
Typical examples follow, illustrating the two structures of litotic double negations. (Note: as you read through these examples you will see other instances of figuration - such as the epanaphora of 6 and the epistrophe of 8 - which exist in both the original text and in the English translation. We have not undertaken a study of these figures at this time. Litotes is a good day's work on its own. But these examples should be enough to indicate how rich Confucius is, not to say how rich Chinese is, for further and broader research.)

\subsection{Non-conditional double negations (non-CDNs)}

1. 子曰：“父母之年，不可不知也。”6

Ž̌ yuẽ: "Fù mǔ zhī nián, bù kě bù zhī yě."

The Master said, "A man should not be unaware of the age of his father and mother." - Passage IV, Section 21

2. 子曰: “...上好信, 则民募敢不用情。”

Zǐ yuē: “... shàng hào xìn, zé mín mò găn bú yòng qíng.”

The Master said, "... when they love trustworthiness, none of the common people will dare not to show their true colours.” - Passage XIII, Section 4

3. 子贡曰: “… 言不可不慎也。”

Ž̈-gòng yuē: “... yán bù kě bú shèn yě.”

Tzu-kung (The Master's disciple) said, “... That is why one really must be careful of what one says." - Passage XIX, Section 25

As the focus of this inquiry is not the familiar emphasis achieving or highlighting function of litotes, we just select three pairs of double negations which do not entail the condition-result relation. In the original Chinese version, they are all constructed with two negators as marked, while in D.C. Lau's translation, not all of them have kept the double negators: in Example 3, he directly uses the strong affirmative (must...) which also illustrates the stressing feature of the Chinese non-conditional DNs.

\subsection{Conditional double negations (CDNs)}

4. 子曰：“不愤不启，甭悱不发。”

Ž̌ yuē: "Bú fề bù qŭ, bù fêi bù fā."

The Master said, "I never enlighten anyone who has not been driven to distraction by trying to understand a difficulty or who has not got into a frenzy trying to put his ideas into words." Passage VII, Section 8

5. 子曰 : “悲礼匄视, 悲礼匄听, 悲礼匄言, 悲礼包动。”

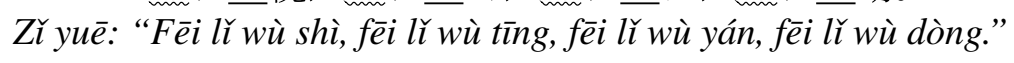

The Master said, "Do not look unless it is in accordance with the rites; do not listen unless it is in accordance with the rites; do not speak unless it is in accordance with the rites; do not move unless it is in accordance with the rites." - Passage XII, Section 1

6. 子曰 : “名丕正, 则言丕顺; 言丕顺, 则事不成; 事麗成, 则礼乐不兴; 礼乐不兴, 则刑罚不中; 刑罚不中, 则民无所 错手足。”

\footnotetext{
${ }^{6} \mathrm{~A}$ meticulous reviewer suggests offering interlinear translation/glossing, but that is extremely hard for ancient Chinese; so we choose to provide phonetic transliteration between each Chinese and English version, as usually done.
} 
Ž̌ yuē: "Míng bú zhèng, zé yán bú shùn; yán bú shùn, zé shì bù chéng; shì bù chéng, zé lì yuè bù xīng; lǐ yuè bù xīng, zé xíng fá bù zhōng; xíng fá bù zhōng, zé mín wú suǒ cuò shŏu zú."

The Master said, "When names are not correct, what is said will not sound reasonable; when what is said does not sound reasonable, affairs will not culminate in success; when affairs do not culminate in success, rites and music will not flourish; when rites and music do not flourish, punishments will not be exactly right; when punishments are not exactly right, the common people will not know where to put hand and foot." - Passage XIII, Section 3

7. 子曰：“已所不欲, 勿施于人。”

Ž̃ yuē: "Jǐ suǒ bú yù, wù shĩ yú rén."

The Master said, "Do not impose on others what you yourself do not desire." - Passage XV, Section 24

8. 孔子曰：“不知命, 无以为君子也 ; 不知礼, 无以立也 ; 歪 知言, 无以知人也。”

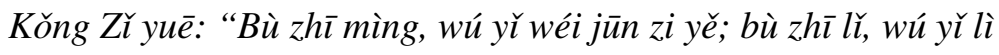
yĕ; bù zhī yán, wú y̌̃ zhī rén yě."

Confucius said, "A man has no way of becoming a gentleman unless he understands Destiny; he has no way of taking his stand unless he understands the rites; he has no way of judging men unless he understands words." - Passage XX, Section 3, ending sentence of The Analects

There are 15 double negations in the five sentences. All of them are condition-result DNs. All the first Chinese negators marked out with waves perform as conditions, though in their English versions they may turn out in the attributive clause, as with Example 4, or in the clause of time, as with Example 6, and even in the object clause, as with Example 7, in addition to the typical negative conditional clause of unless as evidenced in Examples 5 and 8. Of each pair, the second Chinese negator, line-marked, indicates the corresponding result or effect. The condition-result or cause-effect DNs stand out most saliently in The Analects, not only due to the overwhelming quantity of 66 pairs, but also because of the enduring significant lessons they have successfully conveyed. However, previous research, both into litotes (which has not obviously noted this subtype ${ }^{7}$ ) and into The Analects (which has not well commented on this pattern), leaves much to explain. Why should the ancient sages (represented by Confucius) so frequently state their views in condition-result double negations? What privileged function do CDNs serve and why is this function so consonant with the argumentative style of The Analects?

These questions have compelling cultural implications as well. Many of The Analects' most efficient expressions have entered Chinese culture with proverbial status, often as chengyu [8], and this includes its CDNs. Burke long ago suggested that proverbs, adages, and other condensed opinions or attitudes provide us with "equipment for living," highly convenient and portable ways "of arming us to confront perplexities and risks" in everyday life ([5]:61; see also 293-304). They provide a strategy for acting and they frequently imply the reasons for doing so. They are, in a very real sense, the taglines of arguments

\footnotetext{
${ }^{7}$ Quite a few books on figures of speech have touched upon this type (not... + without/unless), but not yet used the name of conditional double negation, e.g. Xu ([43]:283): "We can't learn English well without watching out for idiomatic ways of saying things."; and "You will not succeed unless you work harder." In Farnsworth ([14]:210), when discussing litotes' function of definition, he actually cites a CDN created by Melville in Moby-Dick: "Had these Leviathans been but a flock of simple sheep, pursued over the pasture by three fierce wolves, they could not possibly have evinced such excessive dismay" ([32]:362) (The italics in the last example are made by the author to be consistent with the other two.) So we have a reason to treat CDN as a subtype of contradictory litotes though a $\mathrm{CDN}$ is not entirely the same as its corresponding affirmative.
} 
for culturally sanctioned conduct and belief (as illustrated in 5.3). We also know that proverbs, adages, and so on, are heavily figured in all languages: they frequently exhibit rhyme, assonance, isocolon, various strategies of repetition, and the like. Figuration is what makes them cognitively 'sticky'; that is, salient upon first hearing, subsequently memorable, prone to cultural propagation. Fahnestock, picking up from a strain in Aristotle, tells us that figures

epitomize lines of argument that have great applicability and durability, and though these lines can be paraphrased in roundabout ways, they gain their greatest force in the stylistic concision of a recognizable figure. [13]:xii

Combining Burke's and Fahnestock's (and Aristotle's) insights, then, we see that the CDNs of The Analects not only deploy important argumentative functions for Confucius and his milieu, but they have done so culturally in Chinese for millennia, and continue to do so.

In answering the questions of what function CDN litotes serve and why that function is consonant with the argumentative style of The Analects, then, we are also answering questions that are suggestive about Chinese discourse and Chinese styles of argumentation as well. There are potentialities here for corpus research of a new sort: Are litotes more common in Chinese than in English? Is the presence of litotes proportionally significant among Chinese adages? In what contexts are they most prevalent? And the same questions can be asked for the entire panoply of rhetorical figures, with tremendous possibilities for charting universal, intra-cultural, inter-cultural, and cross-linguistic patterns of reasoning.

\subsection{Logical function of CDN litotes}

Logos in Aristotle's Rhetoric comes in two basic flavours - by way of example (induction) or by way of enthymeme, which Aristotle glosses as rhetorical syllogism (deduction) - and Aristotle demonstrates his preference for the latter: "[s]peeches that rely on examples are as persuasive as the other kind, but those which rely on enthymemes excite the louder applause" ([1]:26). The two modes are equal in persuasiveness, but deduction always feels somehow more powerful, certainly in Aristotle's treatment. The Philosopher would have approved, then, of The Analects. All the above conditional double negation pairs function as, or contribute to, enthymemes, often characterized by two traits ([1]:28): incompleteness (omission of one or more propositions) and probability (rather than certainty) of one or more premises. The CDN litotes of The Analects fulfill both of these requirements.

\subsubsection{Achieving high probability}

The conditional double negation sayings of The Analects are almost all of a probable nature, but they impress us as highly acceptable or extremely convincing. However - and this is the crucial point for the argumentative deployment of litotes - their affirmative counterparts often sound vulnerable. Take Example 4, “不愤不启, 丕悱不发。” (“I never enlighten anyone who has not been driven to distraction..."), which is an adage frequently cited to justify kairotic education. Its affirmative sounds far from bright ("I always enlighten anyone who has been driven to distraction..."), and perhaps arrogant; we assume that even if the pupil has been driven to distraction, the Master may still not enlighten him if he does not show due respect, or if they are not at the right place or if some other required conditions are missing. Or, take 7, “已所否欲, 匀施于人。” (“Do not impose on others what you yourself do not desire.") is irrefutable; but its direct affirmative, "Impose on others what you yourself desire" is highly problematic. The same with Example 8, “不知命, 无以为君子也” (“A man has no way of becoming a gentleman unless he understands Destiny") is unquestionably much more acceptable than its affirmative, “知命可为君子也” (“A man becomes a gentleman if he understands Destiny”), for “understands 
Destiny" is just one necessary condition to be a gentleman who actually needs many other conditions to satisfy the qualifications.

To sum up, in each condition-result double negation pair, the condition is very often a necessary but not sufficient one. A non-sufficient condition cannot lead to a solid result. However, in the double negation, the Master wisely avoids the vulnerability of the corresponding affirmative proposition, by only stressing the indispensability of the necessary condition. ${ }^{8}$ Its probability, therefore, is increased high enough to resist almost all potential attacks. Or we may conclude that a proposition established by the conditional double negation proves much more acceptable with high probability in logic.

\subsubsection{Making a sophisticated major premise}

A typical rhetorical syllogism/enthymeme not only features probability, but truncation as well, often appearing with one or two propositions, leaving an implied reason or conclusion for the audience to infer, which not only achieves economy but also engages more interaction between the two parties [4]. This is where conditional double negation expressions perform their outstanding role. The two brief dialogues below between Confucius and his son, Boyu, illustrate well the persuasive brevity of the CDNs.

9. 子曰: “学《诗》乎? ” (Have you studied Shi?)

对曰: “未也。” (Not yet.)

子曰: “不学《诗》, 无以言。” (Whoever doesn’t study Shi cannot speak well.)

10. 子曰: “学《礼》乎? ” (Have you studied $L i$ ?)

对曰: “未也。” (Not yet.)

子曰: “不学《礼》, 无以立。” (Whoever doesn’t study $L i$ cannot establish himself.) $)^{9}-$ From Passage XVI, Session 13

These two dialogues took place in two days when Confucius inquired of his son about his study of the two classics. After receiving his frank replies, the Father each time instructed with just one nonimperative sentence; however, according to the context of that passage the son immediately studied the relevant text. That is, Boyu obeyed both instructions, though no instructions were in fact given; rather, he was given epitomized arguments framed by litotes. These two conversations present us with two forceful enthymemes with the major and minor premises, but leaving the conclusions for the interlocutor to deduce by himself:

Whoever doesn't study Shi cannot speak well.

(Major premise)

[I have] Not [studied Shi] yet.

I cannot speak well unless I study Shi.

(Minor premise)

(Inferred conclusion)

Whoever doesn't study $L i \underline{\text { cannot establish himself. (Major premise) }}$

[I have] Not [studied $\mathrm{Li}$ ] yet.

I cannot establish myself unless I study $\mathrm{Li}$.

(Minor premise)

(Inferred conclusion)

\footnotetext{
${ }^{8}$ Even if the condition is sufficient, it is still often seen in DN, for example in Laotse's adage: 夫唯丕争, 故无尤。

It is because he does not contend that he is without reproach. [26]

Here, “争 (contend)" is a sufficient condition of “尤 (reproach)”.

${ }^{9}$ These translations are partially done by the author, as Lau's version is not desirable enough. Shi and $L i$ are two classics, the former is a collection of poems reflecting life in Zhou Dynasty (11-6BC), the latter, a compilation of rituals observed in preQin periods.
} 
(For convenience, instead of displaying the minor premises first as in the dialogues, we list all the propositions in the sequence of a normal syllogism.) Here we clearly see the Father's "instruction" in two major premises with high probability which impels his argument, and we see it from his son's perspective, as the inferential structure of enthymemes should be constructed.

Almost all the conditional double negation expressions in The Analects serve as major premises to construct enthymemes either in combination with another proposition, or in certain contexts as oneproposition rhetorical syllogisms. For example, suppose one student, curious about the kitchen of the school canteen, is discussing with his classmate:

A: Let's have a look at the kitchen.

B: Do not look unless it is in accordance with the rites/allowed or invited.

B's terse indirect answer is an enthymeme which entails a persuasive syllogism:

Do not look unless allowed or invited. (Major premise)

We are not allowed or invited.

(Implied minor premise)

We should not have a look [at the kitchen]. (Inferred conclusion)

The above three cases indicate that by using a CDN statement as a major premise, the speaker can adroitly achieve conversational sophistication of economically putting forth his opinion, in a convincing and even euphemistic way. Litotes provides a "highly resilient" strategy of claim-formulation ([29]:129), because it crystalizes the "two-sided vision inherent in every denial of its contrary" ([31]:121).

\subsubsection{Elaborating a strict definition}

In addition to achieving high probability and serving as nuanced major premises, the conditional double negations in The Analects sometimes are also used to aid in making a strict but elaborate definition, for example:

11. 颜渊问仁。子曰: “克己复礼为仁。…”颜波曰: “请问其目。” 子曰: “悲礼勿视, 悲礼勿听, 悲礼勿言, 悲礼匄动。” 颜波曰:

“回虽不敏, 请事斯语矣。”

Yán Yuān wèn rén. Zì yuē: "kè jǔ fù lǐ wéi rén...." Yán Yuān yuē:

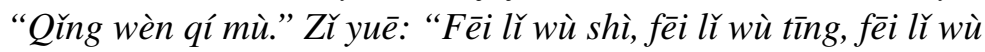
yán, fềi lı̌ wù dòng." Yán Yuān yuē: "Huí suī bù mǐn, qǐng shì sī yŭ

y̌̆."

Yen Yuan (the Master's favorite disciple) asked about benevolence. The Master said, "To return to the observance of the rites through overcoming the self constitutes benevolence..." Yen Yuan said, "I should like you to list the items." The Master said, "Do not look unless it is in accordance with the rites; do not listen unless it is in accordance with the rites; do not speak unless it is in accordance with the rites; do not move unless it is in accordance with the rites." Yen Yuan said, "Though I am not quick, I shall direct my efforts towards what you have said." - Passage XII, Section 1

The term, benevolence (仁), is the kernel concept in The Analects, which might even be employed to summarize Confucianism as a whole. One brief statement is not adequate to convey its rich content, while loose interpretation may possibly harm its accuracy. A group of conditional double negations, however, can be both elaborate and, with proven high probability, not lacking serious precision. So CDN elaboration is a ready and robust tool for defining. 


\section{CDN litotes as epistemic}

Up to now, we have seen that conditional double negation litotes in The Analects performs a very strong logical function. These highly prized CDN adages, often as major premises, have been passed down, generation after generation, solidly establishing themselves as part of common sense, shared knowledge and guiding principles - the doxa - applied to various arguments in all domains, from daily activity to scholarly research; and they have extended gradually beyond Chinese culture to other cultures.

In this light, the CDN litotes, when employed to state things generally, prove to be knowledge generative or technically speaking, epistemic. Perelman and Olbrechts-Tyteca in the manifesto-like "Conclusion" of The New Rhetoric: A Treatise on Argumentation, note that "[w]e combat uncompromising and irreducible philosophical oppositions presented by all kinds of absolutism: dualisms of reason and imagination, of knowledge and opinion" ([37]:510). This is an ethical statement, of course, enforcing the Belgians' commitment to an argumentation that fully accommodates, respects, and advances values. But it is an epistemic statement as well, a key part of their credo for an ethics of reason and the warrants of knowledge. Their argumentation justifies that opinions to which the strong "adherence of minds" ([37]:45) is forged should be no other than securely founded knowledge. CDN expressions with high probability as we see above (Examples 4, 7, 8, etc.) are undoubtedly well justified opinions which can be catalogued as one type of knowledge, and litotes, we therefore also see, is a figure that effectively epitomizes and successfully propagates such knowledge.

Masse, in his research on the epistemic dimensions of litotes in early modern scientific discourse, summarizes the conflicting features of oppositional knowledge: "In the one case, oppositional knowledge leads to algorithmic succinctness; on the other, it provides stumbling and building blocks, and thus loquacity" ([29]:121). The first case is epitomized by CDN litotes.

Not all litotes are epistemic, however, from what we have seen; judging the three subtypes identified above - contradictory, contrary, relative - we note that the last two usually offer situational responses which do not generalize or are not serious enough to propagate as knowledge. At least, their epistemic power requires more evidence than we could find, or than The Analects appears to offer. Rather, it is the contradictory type, conditional double negation in particular, that generates views rational enough to be treated as knowledge. As to the features of the litotes-generating knowledge, besides the algorithmic succinctness Masse identifies, we conclude that what CDN knowledge features most, is its high probability which can well justify its objectivity and acceptability.

\section{Conclusion}

The rich variety of negators in ancient Chinese may partially account for the pervasiveness of DN litotes in The Analects; however, we argue that what is important about them lies in the various argumentative functions they successfully perform. With regard to the function of litotes, previous studies have mainly revealed its highlighting ([38]), evaluative ([19]), understating ([14]) roles, which are primarily vehicles of ethos (especially the last two in combination). While some litotes in The Analects certainly exhibit the highlighting function and the ethotic features of being euphemistic, modest, or cautious, we show that the most prominent function of the most prominent litotes, conditional double negation, is to achieve the strong logical function, the irresistible high probability in particular, and hence correspondingly realize the epistemic power of knowledge producing, accumulating and disseminating.

This epistemic logical function of litotes contributes to the project of shedding a new light on figure studies, of freeing them from the aesthetic cave, to reveal the cognitive dimensions and the argumentative 
contributions they make to discourse. More particularly, our exploration of this litotic function, like the other contributions to this special issue, contributes to the enterprise of computational rhetoric, the enterprise of plumbing such functions with the powerful machines and perceptive algorithms of our age. Because litotes is a trope, it implicates directly the semantics of discourse, making it especially valuable for such meaning-probing tasks as text summarization and argument mining. But because of its schemic elements - its morpholexical-syntactic signatures of negation - litotes is also more tractable computationally than most semantic figures.

Among the diverse goals we seek in this essay, we would be most pleased to find it has sparked more and deeper studies into litotes, to begin redressing the great disparity between the scanty research and universality of litotes. Viva litotes!

\section{Acknowledgements}

I would like to thank very gratefully, Randy Allen Harris, for his tremendous contribution to this article - from the early stage of enlightening discussions to the later period of very substantial revision and meticulous edits in all aspects. I regard this work as definitely coauthored, which is one of the reasons I opt for the academic we throughout, to indicate the plurality of this research. But Prof Harris resolutely left out his name. [Editor's note: I have been firm on this point not because of any wish to dissociate myself with this paper, nor with the superb research of Ying Yuan, but because I regard it as bad form for an editor to include work of his/her own in a volume he/she has edited. I have also, of course, as all editors do, put in an oar with other contributions to this volume, and even taken the rudder for short times - RAH]. I also wish to thank sincerely Jeanne Fahnestock, Yameng Liu, Mingan Luo, Chrysanne Di Marco, Jelena Mitrović, and two anonymous reviewers who have greatly encouraged and benefited this exploration in various ways. Further, this research has been supported by Chinese National Social Science Fund Project: "On Argumentative Textual Functions of Major Tropes and Schemes" (15BYY178).

\section{References}

[1] Aristotle, Rhetoric, Random House, New York, 1954. Translated by W.R. Roberts.

[2] Aristotle, The Complete Works of Aristotle, Vol. 1, J. Barnes, ed., Princeton University Press, Princeton, 1984 (the revised Oxford translation).

[3] J. Austen, Sense and Sensibility, Athenaeum Society, New York, 1892.

[4] L.F. Bitzer, Aristotle's enthymeme revisited, Quarterly Journal of Speech 45(4) (1959), 399-408. doi:10.1080/ 00335635909382374.

[5] K. Burke, The Philosophy of Literary Form: Studies in Symbolic Action, Louisiana State University Press, Baton Rouge, 1941.

[6] K. Burke, Definition of man, The Hudson Review 16(4) (1963), 491-514. doi:10.2307/3848123.

[7] A. Carnegie, The road to business success, in: The Empire of Business, Doubleday, Garden City, 1902, pp. 3-18.

[8] L. Chien and R.A. Harris, Scheme trope chroma chengyu: Figuration in Chinese four-character idioms, Cognitive Semiotics 6(1) (2010), 155-178. doi:10.1515/cogsem.2010.6.spring2010.155.

[9] N.L. Christiansen, Figuring Style: The Legacy of Renaissance Rhetoric, The University of South Carolina Press, Columbia, 2013.

[10] Confucius, The Analects, Penguin, New York, 1979. Translated by D.C. Lau.

[11] Confucius, [孔子], 论语·大学.中庸, 李浴华, 马银华译注, 三晋出版社, 太原, 2008.

[12] F.P. Donnelly, Homeric litotes, The Classical Weekly 23(18) (1930), 137-140. doi:10.2307/4389437.

[13] J. Fahnestock, Rhetorical Figures in Science, Oxford University Press, New York, 1999.

[14] W. Farnsworth, Classical English Rhetoric, David R. Godine, Boston, 2011. 
[15] B. Franklin, Madison Debates (17 September 1786) [Internet], The Avalon Project, Yale Law School, New Haven [cited 2017 August 8]. Available from: http://avalon.law.yale.edu/18th_century/debates_917.asp.

[16] J. Galsworthy, The Dark Flower, the Complete Works of John Galsworthy, Vol. 10, Charles Scribner's Sons, New York, 1926.

[17] M.K. Gao, [高名凯], 汉语语法论, 商务印书馆, 北京, 1986.

[18] A.W. Hass, Hegel and the Art of Negation: Negativity, Creativity and Contemporary Thought, I. B. Tauris, London, 2014.

[19] M.E. Hoffmann, Negatio Contrarii: A Study of Latin Litotes, Van Gorcum, Assen, 1987.

[20] L. Horn, Lie-toe-tease: Double negatives and unexcluded middles, Philosophical Studies 174(1) (2017), 79-103. doi:10. 1007/s11098-015-0509-y.

[21] L.R. Horn, A Natural History of Negation, The University of Chicago Press, Chicago, 1989.

[22] L.R. Horn, Duplex, negatio, affirmat, ... the economy of double negation, in: Proceedings of the 27th Regional Meeting of the Chicago Linguistic Society, Part 2: Parasession on Negation, 1991, pp. 80-106.

[23] L.R. Horn (ed.), The Expression of Negation, Walter de Gruyter, Berlin, 2010.

[24] H.T. Huang, [黄衡田], 英语辞格辨析, 华中科技大学出版社, 武汉, 2015.

[25] R.A. Lanham, A Handlist of Rhetorical Terms, 2nd edn, University of California Press, Berkeley, 1991.

[26] Laotse, The Wisdom of Laotse, The Modern Library, New York, 1948. Translated by Y.T. Lin.

[27] Y.M. Liu, [刘亚猛], 追求象征的力量, 三联书店, 北京, 2004.

[28] S.X. Lv, [吕叔湘], 吕叔湘集, 中国社会科学出版社, 北京, 2001.

[29] V. Masse, Opposition as a technique of knowing in cosmographical literature: Litotes, epanorthosis, Intellectual History Review. 24(1) (2014), 113-134. doi:10.1080/17496977.2013.841386.

[30] M. Mayer, Franz Kafkas Litotes: Logik und Rhetorik der Doppelten Verneinung, Wilhelm Fink, Paderborn, 2015.

[31] E. McCutcheon, Some notes on litotes in Thomas More's The History of King Richard III, Moreana 38(2) (2001), 91-110. doi:10.3366/more.2001.38.2.8.

[32] H. Melville, Moby Dick: Or, the White Whale, LC Page and Company, Boston, 1892.

[33] Merriam-Webster's English Dictionary [Internet], Litotes, [cited 2017 Aug 08], [about 1 screen]. Available from: https:// www.merriam-webster.com/dictionary/litotes.

[34] W. Morris (ed.), The American Heritage Dictionary of the English Language, New College edn, Houghton Miffiin, Boston, 1982, Litotes.

[35] L. Neuhaus, On the relation of irony, understatement, and litotes, Pragmatics \& Cognition 23(1) (2016), 117-149. doi:10. 1075/pc.23.1.06neu.

[36] Oxford English Dictionary [Internet], Litotes, [cited 2017 Aug 08], [about 1 screen]. Available from: www.oed.com.

[37] C. Perelman and L. Olbrechts-Tyteca, The New Rhetoric: A Treatise on Argumentation, University of Notre Dame Press, Notre Dame, 1969. Translated by J. Wilkinson and P. Weaver.

[38] P. Pontier, The litotes of Thucydides, in: Thucydides Between History and Literature, A. Tsakmakis and M. Tamiolaki, eds, De Gruyter, Berlin, 2013, pp. 353-370.

[39] J. Royce, Encyclopedia of Religion and Ethics, Vol. 9, J. Hasting, ed., Charles Scribner's Sons, New York, 1917, Negation, pp. 264-271.

[40] R.L. Stevenson, The pavilion on the links, Potter's American Monthly 15 (1880), 334-341.

[41] T. Van der Wouden, Litotes and downward monotonicity, in: Negation: A Notion in Focus, H. Wansing, ed., De Gruyter, Berlin, 1996, pp. 145-167.

[42] L. Wang, [王力], 古代汉语, 中华书局, 北京, 1981 .

[43] P. Xu, [徐鹏], 英语辞格, 商务印书馆, 北京, 1996. 